\title{
LXVIII. On the comparison of two self-inductions
}

\section{Professor A. Anderson}

To cite this article: Professor A. Anderson (1911) LXVIII. On the comparison of two self-inductions, Philosophical Magazine Series 6, 21:125, 608-610, DOI: 10.1080/14786440508637069

To link to this article: http://dx.doi.org/10.1080/14786440508637069

曲 Published online: 21 Apr 2009.

Submit your article to this journal

Џll Article views: 4

Q View related articles 두 
LXVIII. On the Comparison of Two Self-Inductions. By Professor A. Anderson *

TWWO conductors connected in parallel, whose resistances are $P$ and $Q$, coefficients of self-induction $L$ and $N$, and coefficient of mutual induction $M$, are equivalent to a

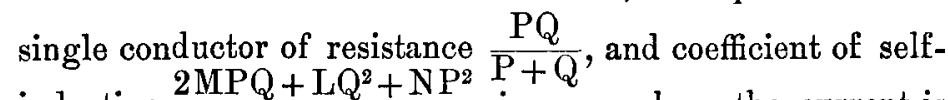
induction $\frac{2 M P Q+L Q^{2}+N P^{2}}{(P+Q)^{2}}$, in cases where the current is not oscillatory. It follows that a system consisting of a coil of resistance $\mathrm{P}$ and coefficient of self-induction $\mathrm{L}$ connected in parallel with a non-inductive resistance $S$ has an inductance equal to $\frac{\mathrm{ISS}^{2}}{(\mathrm{P}+\mathrm{S})^{2}}$.

It is thus possible, by shunting a coil with a non-inductive resistance, to reduce its effective self-inductance, and to make the latter equal to that of another coil whose coefficient of self-induction is less.

A very easy and, possibly, useful method of comparing the coefficients of self-induction of two coils is readily deduced; and, though it involves a double balance, there is little more experimental difficulty in it than in the measurement of a resistance.

Referring to fig. 1, the coils A and B, of which A has the higher self-induction, are placed in the two arms of

Fig. 1.

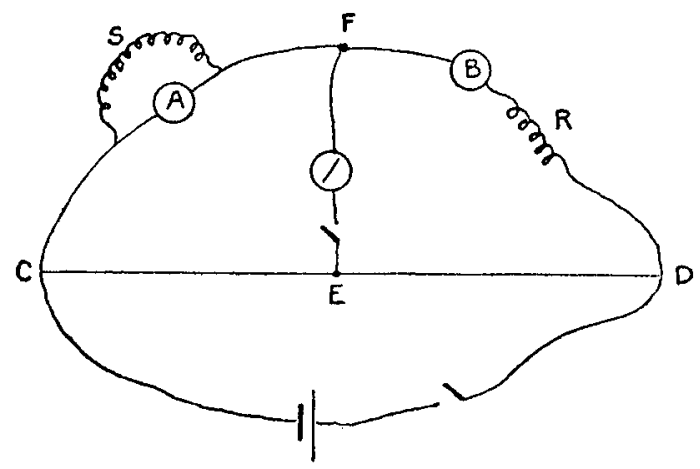

a Wheatstone bridge, $B$ in series with a variable resistance $R$, and $A$ shunted by a variable shunt of resistance $S$. The

* Communicated by the Author. 
resistance $\mathrm{CE}$ is equal to the resistance $\mathrm{ED}$. If the resistance in the arm $\mathrm{DF}$ is equal to that in $\mathrm{CF}$ there will be no permanent current in the galvanometer, and if the self-induction in $\mathrm{DF}$ is equal to that in $\mathrm{CF}$, there will be no transient current when the battery key is put down after the galvanometer key. The method consists in varying $\mathrm{S}$ and $\mathrm{R}$ till both these conditions are fulfilled.

Denoting the resistances of $\mathrm{A}$ and $\mathrm{B}$ by $\mathrm{X}$ and $\mathrm{Y}$, and their coefficients of self-induction by $L$ and $N$, we have, then,

$$
\frac{\mathrm{L}}{\mathrm{N}}=\left(1+\frac{\mathrm{X}}{\mathrm{S}}\right)^{2}, \text { and } \frac{\mathrm{XS}}{\mathrm{X}+\mathrm{S}}=\mathrm{Y}+\mathrm{R} \text {. }
$$

It is possible that $\mathrm{Y}$ may be greater than $\frac{\mathrm{XS}}{\mathrm{X}+\mathrm{S}}$; and, in that case, the resistance $R$ should be in CF in series with the system consisting of $A$ and $S$. Any incon venience of moving the variable resistance $R$ from $D F$ to $C E$ will be avoided by having variable resistances in both arms.

The following experiment will illustrate the ease with which the adjustment can be made.

Resistance of $A=109 \cdot 3$ ohms.

Resistance of $B=14.5$ ohms.

\begin{tabular}{|c|c|l|}
\hline R in ohms. & S in ohms. & $\begin{array}{l}\text { Kick on taking out } \\
\text { Battery Key. }\end{array}$ \\
\hline 0 & $16 \cdot 7$ & Right. \\
10 & $31 \cdot 5$ & Right. \\
20 & 50 & Right. \\
30 & 75 & Right. \\
40 & 109 & Right. \\
50 & 157 & Right. \\
60 & 233 & Right. \\
70 & 371 & Right, but small. \\
80 & 697 & Letit. \\
72 & 414 & Right, ono division. \\
73 & 434 & No kick. \\
74 & 465 & Left, one division. \\
\hline
\end{tabular}

$\mathrm{N}$ the coefficient of self-induction of $\mathrm{B}$ is therefore equal to

$$
\frac{434^{2} \mathrm{~L}}{(434+109 \cdot 3)^{2}} \text {, or } \quad \frac{\mathrm{L}}{\mathrm{N}}=1.56^{*} \text {. }
$$

* Very careful measurements by Mr. W. G. Griffith of the selfinductances of these coils, in which Inord Rayleigh's method was used, gave, for A, 0.236 henry, and, for B, 0.151 henry. 
When the kick is large it is not necessary to have an accurate balance for permanent currents; a rough balance will suffice. But when the transient currents are nearly zero, the permanent balance must be as good as possible.

In the above experiment an ordinary mirror galvanometer of the Thomson type was used.

The following is, perhaps, the easiest way of applying the principle of the method:-

Fig. 2.

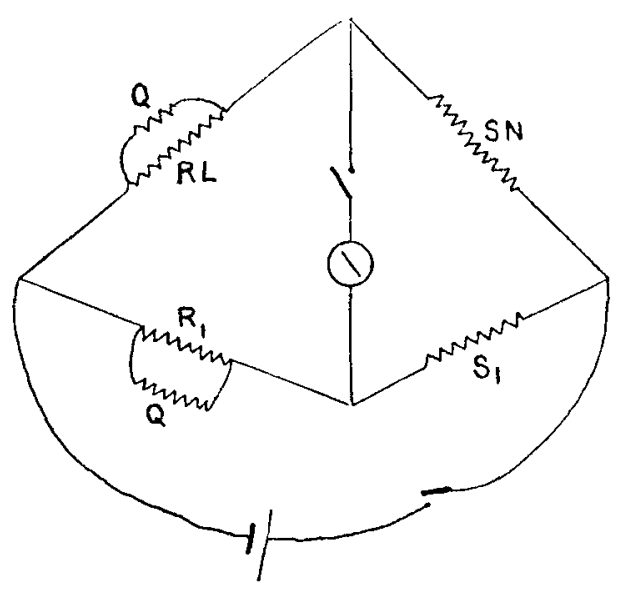

The self-inductions, $\mathrm{L}$ and $\mathrm{N}$, of the coils whose resistances are $R$ and $S$ are to be compared. $R_{1}$ and $S_{1}$ are non-inductive resistances equal, respectively, to $R$ and $S$. There is thus a balance for steady currents. The $Q$ 's are equal non-inductive shunts which are varied till there is no transient current. We have then $N=\frac{\mathrm{LQS}}{\mathrm{L}(\mathrm{R}+\mathrm{Q})}$. Thus $\mathrm{N}$ must not be greater than $\frac{L S}{R}$. Otherwise, the shants must be applied to $S$ and $\mathrm{S}_{1}$.

University College, Galway. March 13, 1911. 